\title{
MANAJEMEN PROYEK ONLINE TRADING SYSTEM PT UNIVERSAL BROKER INDONESIA
}

\author{
Noerlina $^{1}$; Deliusno $^{2}$; Retdonero ${ }^{3}$; Dennis Eryanto ${ }^{4}$
}

\begin{abstract}
The articles purpose was to setting for global project management including determination of project organization, work breakdown structure, network diagram, and project scheduling, whenever in case to avoid the failure of project or minimize the failure and risk of Online Trading System project on PT Universal Broker Indonesia. The research method was literature study by reading books, internet articles, and others references related to subsequent project management and do survey by directly interviewing to those parties whom related to subsequent project. The research result indicates that PT Universal Broker Indonesia's Online Trading System project is executed according to it's schedule and it hits the requirements. By conclusion, good project's planning and controlment start from beginning until the end will assist the project's running to achieve its purpose.
\end{abstract}

Keywords: project management, online trading system

ABSTRAK
Artikel bertujuan merancang suatu manajemen proyek menyeluruh yang meliputi
penentuan tim proyek, struktur tugas, diagram jaringan kerja, dan penjadwalan proyek
sehingga mampu menghindari terjadinya kegagalan proyek atau meminimalisasi
kegagalan dan risiko proyek Online Trading System pada PT Universal Broker
Indonesia. Metode penelitian yang digunakan adalah studi pustaka dengan membaca
buku, artikel dari internet, literatur yang berhubungan dengan manajemen proyek, dan
melakukan studi lapangan melalui wawancara secara langsung dengan pihak yang
bersangkutan dengan proyek. Hasil yang dicapai adalah proyek Online Trading System
yang telah dilaksanakan oleh PT Universal Broker Indonesia berjalan dengan baik
sesuai jadwal yang telah ditentukan dan hasil sesuai dengan permintaan. Simpulan yang
dapat diambil adalah dengan perencanaan dan pengendalian yang baik terhadap proyek
dari awal sampai akhir sangat membantu jalannya proyek untuk mencapai tujuan.
Kata kunci: manajemen proyek, sistem perdagangan online

1, 2, 3,4 Jurusan Komputerisasi Akuntansi, Fakultas Ilmu Komputer, Universitas Bina Nusantara, Jl. K.H. Syahdan No. 9, Palmerah, Jakarta Barat 11480, nurlina@binus.edu 


\section{PENDAHULUAN}

Pada zaman perkembangan teknologi yang sangat pesat sekarang ini, informasi sangat dibutuhkan oleh banyak perusahaan dalam mendukung peningkatan kinerja mereka. Perusahaan sering membuat suatu proyek untuk mengembangkan usahanya sehingga membutuhkan sistem informasi dalam mencapai tujuan dan sasaran yang diinginkan. Informasi dapat disediakan melalui komputer dengan bantuan perangkat lunak.

Dalam menghadapi persaingan pada zaman perkembangan teknologi sekarang ini, perusahaan broker harus melakukan kegiatan operasional menggunakan teknologi informasi agar dapat terus bersaing. Salah satu teknologi informasi yang harus dikembangkan adalah perangkat lunak. Perangkat lunak digunakan untuk memudahkan pelanggan mereka dalam melakukan pemesanan jual maupun beli saham. Dengan demikian, perusahaan broker harus mengembangkan dan membuat perangkat lunak baru yang dapat mendukung kegiatan operasional agar kegiatan operasionalnya dapat dilakukan dengan lebih efektif dan efisien. Salah satu cara agar perkembangan perangkat lunak dapat berjalan dengan baik dan lancar, yaitu menggunakan teknik manajemen proyek sistem informasi.

Dalam membuat suatu proyek sistem informasi, dianggap bahwa awal keberhasilan suatu proyek harus dimulai dengan perencanaan dan penyusunan tahap yang benar serta tahap yang sistematis. Proyek merupakan suatu aktivitas yang baru sehingga tingkat ketidakpastian dan risikonya juga sangat tinggi. Karena tingginya ketidakpastian tersebut, akan lebih sulit untuk memperkirakan tingkat sumber tenaga dan juga akan mempersulit perkiraan waktu yang dikehendaki untuk menyelesaikan suatu proyek.

Pelaksanaan proyek diharapkan dapat dilakukan dengan baik dan terarah maka selama masa pengembangan perlu dilakukan monitoring dan pengendalian untuk mengetahui apakah proyek tersebut sudah berjalan dengan lancar dan sesuai dengan sasaran dan tujuan yang diinginkan. Jika terdapat penyimpangan, diharapkan dapat segera dideteksi dan dapat segera diambil langkah perbaikan (antisipasi). Hal itu karena jika tidak maka akan menghambat pelaksanaan proyek dan menyebabkan waktu dan biaya tidak sesuai dengan estimasi yang diharapkan. Dengan pengawasan yang baik, dapat dilakukan tindakan pencegahan (preventive) terhadap kecenderungan penyimpangan yang mungkin dapat dan akan terjadi. Pelaksanaan proyek itu sendiri juga harus terukur dengan baik, pengukuran itu dapat berdasarkan waktu tempuh pelaksanaan tugas, realisasi anggaran, dan pencapaian sasaran tugas. Itulah yang menentukan pencapaian sasaran proyek secara keseluruhan.

Manajemen proyek yang baik turut menentukan keberhasilan perusahaan dalam merencanakan, melaksanakan, dan mengakhiri proyek. Manajemen proyek yang baik juga harus dapat mengenali apakah suatu proyek dapat memberikan keuntungan atau 
tidak. Keuntungan tidak hanya diukur dari jumlah uang yang diterima dikurangi jumlah uang yang harus dikeluarkan (biaya) tetapi juga diukur dari jumlah usaha dan waktu yang harus dikeluarkan serta tingkat kepuasaan pelanggan dalam menggunakan sistem tersebut.

\section{PEMBAHASAN}

\section{Tinjauan Pustaka}

Manajemen merupakan proses merencanakan, mengorganisasikan, memimpin, dan mengendalikan kegiatan anggota serta sumber daya yang lain untuk mencapai sasaran organisasi (perusahaan) yang telah ditentukan (Soeharto, 2001:21). Proyek merupakan suatu usaha yang bersifat sementara untuk menghasilkan suatu produk atau layanan yang unik (Schwalbe, 2006:4). Manajemen proyek merupakan kegiatan merencanakan, mengorganisasikan, mengarahkan, dan mengendalikan sumberdaya organisasi perusahaan untuk mencapai tujuan dalam waktu tertentu dengan sumber daya tertentu (Budi Santosa, 2003:3).

Setiap proyek mempunyai batasan yang berbeda terhadap ruang lingkup, waktu, biaya, yang biasanya disebut sebagai triple constraint (Tiga Kendala). Setiap proyek manajer harus memperhatikan hal penting dalam manajemen proyek. Pertama, ruang lingkup (scope): Apa yang ingin dicapai dalam proyek? Produk atau layanan apa yang pelanggan harapkan dari proyek tersebut? Kedua, waktu (time): Berapa lama waktu yang dibutuhkan untuk menyelesaikan proyek? Bagaimana jadwal kegiatan proyek akan dilaksanakan? Ketiga, biaya (cost): Berapa biaya yang dibutuhkan untuk dapat menyelesaikan proyek?

Ketiga batasan tersebut bersifat tarik-menarik. Artinya, jika ingin meningkatkan kinerja produk yang telah disepakati dalam kontrak maka umumnya harus diikuti dengan meningkatkan mutu yang selanjutnya berakibat pada naiknya biaya melebihi anggaran. Sebaliknya, bila ingin menekan biaya maka biasanya harus berkompromi dengan mutu dan jadwal. Menurut Schwalbe (Schwalbe, 2006:72-73), pengembangan manajemen proyek terdiri dari lima tahap. Pertama, tahap inisiasi. Inisiasi merupakan proses mengenal dan memulai sebuah proyek baru atau fase proyek. Menurut Schwalbe (2006:72), tindakan yang harus dilakukan manajer proyek dan manajemen senior di dalam inisiasi proyek adalah dengan cepat menentukan sebuah tim proyek yang kuat; Mendapatkan keterlibatan pemegang saham di dalam awal proyek; Menyiapkan analisis lebih detail dari masalah bisnis dan mengembangkan teknik perbandingan proyek; Menggunakan pendekatan fase per fase; Menyiapkan rencana yang berguna dan realistis untuk proyek. 
Kedua, perencanaan. Perencanaan merupakan proses yang paling sulit dan tidak diperhatikan dalam manajemen proyek. Tujuan utama perencanaan proyek adalah sebagai panduan dalam pelaksanaan proyek. Untuk itu, rencana yang dibuat harus realistis dan berguna. Ketiga, eksekusi. Eksekusi proyek melibatkan pengambilan tindakan yang perlu dilakukan untuk meyakinkan bahwa aktivitas di dalam rencana proyek terselesaikan dengan baik. Produk dari proyek dihasilkan selama eksekusi proyek dan biasanya memakan banyak sumber daya untuk diselesaikan. Keluaran yang paling penting adalah hasil kerja atau pengiriman produk. Keempat, pengontrolan. Pengontrolan merupakan proses untuk membandingkan kemajuan proyek dengan objektif proyek, pengawasan penyimpangan dari rencana, dan mengambil tindakan korektif untuk menyesuaikan kemajuan dengan rencana. Kelima, penutupan. Proses penutupan proyek meliputi kegiatan untuk mendapatkan penerimaan pemegang saham dan pelanggan dari produk akhir dan proyek atau fase proyek untuk pemesanan akhir. Hal itu meliputi verifikasi terhadap semua pekerjaan yang sudah diselesaikan dan menyangkut audit proyek.

Menurut Soeharto (Soeharto, 2001:471), Pinto dan Slevin pada tahun 1988 telah menyelidiki lebih dari 400 proyek, dan menemukan CSF yang berikut ini berdasarkan urutannya. Pertama, misi proyek, yaitu harus memiliki tujuan dan arah yang jelas mengenai proyek diadakan. Hal tersebut harus dimengerti oleh tim proyek dan bidang yang terkait di dalam perusahaan serta stakeholders yang memiliki peranan penting. Kedua, dukungan dari manajemen atas. Dukungan dapat diberikan dalam bentuk penyediaan sumber daya yang diperlukan, memberikan otoritas yang cukup untuk pelaksanaan implementasi, mengikuti dan memperhatikan beberapa aspek kritis proyek, serta turun tangan dalam penyelesaiannya. Ketiga, perencanaan dan penjadwalan. Proyek harus memiliki perencanaan dan jadwal secara keseluruhan seperti milestone (suatu kegiatan penting dalam proyek dengan durasi $=0$ ), jadwal penyerahan produk yang dibuat, dan lain-lain. Dalam hal ini, termasuk sistem pelaporan dan monitoring yang efektif untuk mendeteksi kemungkinan adanya penyimpangan. Keempat, konsultasi dengan pemilik proyek. Konsultasi dengan pemilik proyek dari waktu ke waktu selama penyelenggaraan proyek akan sangat memperlancar pelaksanaan tahap implementasi sejauh mana keinginan peranan pemilik. Kelima, personel. Berhubungan dengan memilih, melakukan negosiasi, merekrut, serta pembinaan tim kerja yang efektif. Dengan kata lain, personel berhubungan dengan orang-orang yang cocok ditugaskan ke dalam tim proyek.

Keenam, kemampuan teknis. Pelaksana proyek harus memiliki kemampuan teknis dan menguasai betul-betul teknologi proyek yang akan dikerjakan. Ketujuh, penerimaan dari pihak pemilik proyek. Pemilik proyek, terutama pada akhir tahap implementasi ikut aktif melakukan testing uji coba dan sertifikasi (pemilik proyek menerima produk yang dihasilkan tersebut). Kedelapan, pemantauan, pengendalian, dan feedback, diperlukan guna mengetahui sejauh mana hasil pelaksanaan dibandingkan dengan perencanaan, terutama anggaran. Disini diperlukan metode yang dapat meramalkan hasil kegiatan akhir proyek bilamana kondisi seperti saat pelaporan tidak berubah. Dengan demikian, dapat diadakan koreksi sesuai keperluan. Kesembilan, komunikasi. Terbinanya komunikasi yang baik antara peserta proyek (tim proyek) dan 
stakeholders yang terkait diperlukan untuk mencegah duplikasi kegiatan maupun salah pengertian. Namun dengan komunikasi yang baik akan dapat dibicarakan persoalan yang timbul selama proses implementasi. Kesepuluh, trouble shooting. Mekanisme itu membantu memperkirakan persoalan yang akan terjadi di kemudian hari sehingga jauh sebelumnya sudah diberikan perhatian yang seksama (menangani krisis dan hambatan yang terjadi).

Banyak proyek perangkat lunak mengalami kegagalan karena spesifikasi desain atau waktu dan perkiraan biaya. Kebanyakan permasalahan proyek tidaklah nyata bahkan sampai akhir proyek tersebut. Lyytinen dan Hirschheim mengidentifikasi empat kategori utama kegagalan proyek perangkat lunak. Pertama, kegagalan penyesuaian: kegagalan sistem pada sasaran desain. Hal itu adalah suatu kegagalan teknis dalam pengkodean pada komputer. Kedua, kegagalan proses: kegagalan penyelesaian suatu proyek dengan tepat waktu dan sesuai dengan anggaran. Sistem bekerja secara teknis tetapi tidak ekonomis dan tidak sesuai dengan perencanaan bisnis.Ketiga, kegagalan interaksi: terjadi ketika suatu sistem tidaklah digunakan sesuai dengan rencana. Interaksi antara tim proyek dengan user tidak berjalan dengan sistematis dan efektif. Keempat, kegagalan harapan: terjadi ketika sistem tidak dapat memenuhi syarat yang diharapkan. Sistem mungkin akan menampilkan secara teknis, sesuai dengan waktu maupun anggaran, tetapi mungkin tidak dapat melakukan tugas manajemen.

Menurut Budi Santosa (Budi Santosa, 2004:7), secara garis besar proyek memiliki empat tahap berikut. Pertama, Tahap Konsepsi. Tahap menyusun dan merumuskan gagasan, menganalisis pendahuluan, dan melakukan studi kelayakan. Kedua, Tahap Pendefinisian. Tahap kegiatan penyiapan rencana proyek secara detail dan penentuan spesifikasi proyek secara rinci. Ketiga, Tahap Akuisisi. Tahap kegiatan yang terdiri dari desain, pengadaan fasilitas pendukung maupun material untuk tahap selanjutnya, produksi, dan implementasi. Keempat, Tahap Operasi. Tahap akhir dari suatu proyek dan proyek diserahkan kepada user. Tahap itu terjadi tergantung pada jenis proyek.

Menurut Schwalbe (Schwalbe, 2006:10), sembilan area pengetahuan manajemen memiliki fungsi yang saling terkait satu sama lainnya di dalam area pengetahuan manajemen tersebut. Manajer proyek harus mempunyai pengetahuan dan keahlian di dalam sembilan area ini. Empat inti area pengetahuan manajemen proyek, meliputi manajemen lingkup proyek, waktu, biaya, dan manajemen kualitas. Pengetahuan manajemen itu dapat membantu manajer proyek untuk menentukan sumber daya manusia, komunikasi, risiko, dan manajemen pengadaan proyek.

Sembilan area manajemen proyek sebagai berikut. Pertama, Manajemen Ruang Lingkup Proyek. Menurut Schwalbe (Schwalbe, 2006:167-189), ruang lingkup proyek mencakup semua proses yang terlibat dalam pendefinisian dan pengaturan mengenai segala sesuatu yang termasuk atau tidak di dalam proyek. Hal itu untuk meyakinkan bahwa tim proyek dan stakeholders mempunyai pengertian yang sama mengenai produk 
yang akan diproduksi sebagai hasil proyek dan proses yang akan digunakan dalam memproduksi proyek tersebut. Lima proses utama di dalam manajemen ruang lingkup proyek adalah perencanaan ruang lingkup (scope planning), definisi ruang lingkup (scope definition), membuat Work Breakdown Structure (WBS), verifikasi ruang lingkup (scope verification), dan pengendalian ruang lingkup (scope control)

Kedua, Manajemen Waktu Proyek. Menurut Scwalbe (Schwalbe, 2006:203-231), manajemen waktu proyek meliputi perkiraan berapa lama waktu yang dibutuhkan untuk menyelesaikan perkerjaan, mengembangkan jadwal penerimaan proyek, dan memastikan penyelesaian proyek tepat pada waktunya. Terdapat enam proses utama dalam manajemen waktu proyek yang terdiri dari definisi aktivitas (activity defintion), barisan aktivitas (activity sequencing), aktivitas perkiraan durasi (activity duration estimating), pengembangan jadwal (schedule development), dan pengendalian jadwal (schedule control).

Ketiga, Manajemen Biaya Proyek. Menurut Schwalbe (Schwalbe, 2006:251-257), Project Cost Management terdiri dari aktivitas persiapan dan pengaturan anggaran untuk proyek. Manajemen biaya proyek melibatkan proses yang dibutuhkan untuk meyakinkan bahwa proyek terselesaikan dengan anggaran yang dianjurkan. Seorang manajer proyek harus dapat meyakinkan bahwa proyek sudah didefinisikan dengan baik, mempunyai perkiraan waktu dan harga yang akurat, dan mempunyai anggaran yang realistis dimana tim proyek terlibat dalam hal penganjuran tersebut. Proses yang terlibat dalam manajemen biaya proyek, yaitu perkiraan biaya (Cost Estimating) dan penganggaran biaya (Cost Budgeting).

Keempat, Manajemen Kualitas Proyek. Menurut Schwalbe (Schwalbe, 2006:293294), tujuan utama manajemen kualitas proyek adalah menyakinkan bahwa proyek akan memenuhi kebutuhan yang akan diambil. Tim proyek harus mengembangkan hubungan yang baik dengan stakeholders kunci, khususnya pelanggan utama proyek tersebut untuk mengerti kualitas yang ada di dalamnya. Jika stakeholders proyek tersebut tidak puas dengan kualitas manajemen proyek atau hasil produk suatu proyek maka tim proyek harus membetulkan ruang lingkup, waktu, dan biaya untuk memenuhi kebutuhan stakeholders dan harapannya. Oleh karena itu, tim proyek harus mengembangkan hubungan kerja yang baik dengan sesama stakeholders dan mengerti kebutuhan mereka. Proses yang terlibat dalam manajemen kualitas proyek adalah perencanaan kualitas (Quality Planning), meyakinkan kualitas (Quality Assurance), dan pengontrolan kualitas (Quality Control)

Kelima, Manajemen Sumber Daya Manusia Proyek. Menurut Schwalbe (2006:345-346), manajemen sumber daya manusia proyek melibatkan proses yang dibutuhkan untuk melakukan efektivitas dari penggunaan orang yang terlibat dengan proyek. Manajemen sumber daya manusia menyangkut semua stakeholders proyek, seperti sponsor, pelanggan, anggota tim proyek, staf pendukung, para penjual yang mendukung proyek, dan lain-lain. Proyek utama yang terlibat dalam manajemen sumber 
daya manusia proyek adalah perencanaan sumber daya manusia (Human Resource Planning), perekrutan tim proyek (Acquiring the Project Team), pengembangan tim proyek (Developing The Project Team), dan pengaturan tim proyek (Managing The Project Team).

Keenam, Manajemen Komunikasi Proyek. Menurut Schwalbe (2006:388), tujuan manajemen komunikasi proyek adalah untuk meyakinkan waktu dan turunan yang benar, pengumpulan, penyebaran, penyimpanan, dan penempatan informasi proyek. Proses utama dalam manajemen komunikasi proyek adalah perencanaan komunikasi (Communication Planning), pendistribusian informasi (Information Distriution), pelaporan kinerja (Performance Reporting), dan pengaturan stakeholders (Managing Stakeholders).

Ketujuh, Manajemen Risiko Proyek. Menurut Schawlbe (2006:425-429), manajemen risiko proyek merupakan seni dan ilmu pengindetifikasian, penganalisaan, dan penanggapan terhadap risiko melalui siklus hidup dari proyek dan berpatokan pada tercapainya tujuan proyek. Tujuan manajemen risiko proyek dapat dipandang sebagai peminimalan risiko negatif potensil dan pemaksimalan risiko positif potensial. Menurut Pressman (2003:146-149), risiko selalu melibatkan dua karakteristik, yaitu ketidakpastian (Uncertainty) dan kerugian (Loss).

Kedelapan, Manajemen Pengadaan Proyek. Menurut Schwalbe (2006:467-471), pengadaan (procurement) proyek mempunyai arti mendapatkan barang atau jasa dari sumber daya luar. Manajemen pengadaan proyek itu sendiri meliputi proses yang dibutuhkan untuk mendapatkan barang atau jasa untuk proyek dari luar. Enam proses utama dalam manajemen pengadaan proyek adalah merencanakan pembelian dan perolehan (Planning, Purchases, and Acquisitions), merencanakan kontrak (Planning Contracting), meminta tanggapan penjual (Requesting Seller Responses), memilih penjual (Selecting Seller), mengatur kontrak (Administering The Contract), dan menutup kontrak (Closing the Contract).

Kesembilan, Manajemen Integrasi Proyek. Menurut Schwalbe (2006:116-117), manajemen integrasi proyek meliputi proses yang terlibat dalam mengkoordinasi semua area pengetahuan manajemen proyek lain melalui daur hidup proyek. Hal itu untuk meyakinkan bahwa semua elemen proyek digunakan bersama pada waktu yang tepat untuk menyukseskan suatu proyek. Tujuh proses utama dalam manajemen integrasi proyek adalah mengembangkan Project Charter, membangun preliminary project scope statement, membangun perencanaan manajemen proyek, mengarahkan dan mengatur eksekusi proyek secara langsung, memantau dan mengendalikan kerja proyek, menampilkan pengontrolan perubahan yang terigentrasi, dan menutup proyek. 


\section{Metode Penelitian}

Untuk mencapai tujuan yang diinginkan, digunakan beberapa metode yang lebih terarah dan mendukung serta dapat dipertanggungjawabkan kebenarannya. Metode tersebut meliputi metode pengumpulan data dan metode analisis data. Dalam metode pengumpulan data terdapat dua hal, yaitu pertama, studi kepustakaan. Studi kepustakaan, yaitu merupakan suatu penelitian dengan cara mempelajari buku sebagai pedoman dalam perancangan, literatur yang berhubungan dengan sistem monitoring rencana kerja, dan anggaran serta catatan yang diperoleh selama perancangan sistem. Kedua, studi lapangan, yaitu suatu penelitian yang dilakukan untuk memperoleh informasi di luar studi kepustakaan, antara lain observasi langsung, yaitu suatu kegiatan yang dilakukan dengan cara mengamati secara langsung objek yang sedang diteliti, dalam hal ini dilakukan pengamatan langsung terhadap kegiatan operasional perusahaan dan wawancara, yaitu suatu cara pengumpulan data dengan cara tanya - jawab secara langsung dengan objek yang akan diteliti, dalam hal ini dilakukan tanya - jawab dengan pembimbing yang membimbing penelitian ini.

Metode analisis data dilakukan dengan mengolah data yang ada dengan cara membuat Work Breakdown Structure (WBS) sebagai langkah yang akan dilaksanakan dalam proyek Online Trading System pada PT Universal Broker Indonesia; Menggunakan diagram jaringan kerja dalam bentuk CPM untuk mengestimasi waktu yang digunakan dalam proyek; Menggunakan Microsoft Project untuk merancang penjadwalan proyek mengenai waktu, tahapan kegiatan dan predecessors.

\section{Hasil dan Pembahasan}

Tujuan bisnis pembuatan proyek Online Trading System adalah menyediakan suatu fasilitas bagi nasabah untuk eksekusi jual, eksekusi beli, perubahan (amend), pembatalan (withdraw), monitoring status order jual beli secara realtime, pengecekan portofolio, menampilkan history transaksi, dan monitoring harga saham secara realtime. Menurut manajer proyek PT Universal Broker Indonesia, dengan Online Trading System akan mempermudah nasabah dalam melakukan eksekusi jual maupun beli saham. Dengan melakukan pengembangan sistem ini diharapkan dapat mengurangi kesalahan yang akan terjadi pada saat melakukan eksekusi jual maupun beli

Dalam pengembangan proyek Online Trading System yang akan dilaksanakan pada PT Universal Broker Indonesia, perusahaan telah menunjuk Bapak Koento Wahyudi selaku Kepala departemen IT sebagai Project Leader. Pra-perencanaan dan pengumpulan data proyek yang diperlukan, dilakukan mulai dari perusahaan beralih kepemimpinan. Setelah pra-perencanaan dan pengumpulan data proyek telah selesai, dilakukan perencanaan oleh Project Leader kemudian langsung membentuk tim proyek yang dibagi menjadi empat bagian, yaitu bagian server side, client side, database/network, dan analysis/design. Setelah membentuk tim proyek, Project Leader langsung melakukan pembagian tugas kepada masing-masing bagian dalam tim proyek. 
Online Trading System ini dibuat untuk memenuhi beberapa kebutuhan perusahaan. Perpindahan sistem tradisional menjadi terkomputerisasi dan terintegrasi akan menimbulkan perubahan yang baru, antara lain meliputi pergantian sistem baru mengakibatkan penambahan perangkat lunak dan perangkat keras agar dapat disesuaikan dengan sistem baru yang merupakan tanggung jawab PT Universal Broker Indonesia; Penambahan infrastruktur jaringan untuk mendukung Online Trading System; Perubahan terhadap strategi bisnis yang disebabkan oleh pergantian sistem tradisional ke komputerisasi.

Kebutuhan layanan yang dibutuhkan dalam Online Trading System adalah dapat mempermudah nasabah dalam memantau atau memonitor harga secara realtime; Dapat mempermudah nasabah dalam melakukan eksekusi jual maupun beli, perubahan (amend), pembatalan (withdraw), dan pemantauan (monitoring) status order jual beli secara realtime; Dapat mempermudah nasabah dalam melakukan memantau maupun mengecek statement atau portofolionya; Dapat mempermudah nasabah dalam memantau terhadap history transaksi.

Dalam pengembangan proyek Online Trading System pada PT Universal Broker Indonesia terdapat beberapa faktor kunci kesuksesan dari proyek tersebut yang terdiri dari, pertama, Misi Proyek. Tujuan bisnis pembuatan proyek Online Trading System ini adalah menyediakan suatu fasilitas bagi nasabah untuk eksekusi jual, eksekusi beli, perubahan (amend), pembatalan (withdraw) dan monitoring status order jual beli secara realtime, pengecekan portofolio, menampilkan history transaksi, dan monitoring harga saham secara realtime. Kedua, Dukungan dari Manajemen Atas. Pada pelaksanakan proyek Online Trading System terdapat dukungan dari Manajemen Atas berupa penyediaan sumber daya yang diperlukan, memberikan otoritas yang cukup untuk pelaksanaan implementasi, mengikuti dan memperhatikan beberapa aspek kritis proyek.

Ketiga, perencanaan dan penjadwalan. Proyek Online Trading System memiliki perencanaan dan jadwal secara keseluruhan, jadwal pengerjaan proyek yang dibuat, dengan menggunakan Gant Chart, WBS (Work Breakdown Structure), dan CPM (Critical Path Method). Dalam hal ini termasuk sistem pelaporan dan monitoring yang efektif untuk mendeteksi kemungkinan adanya penyimpangan. Keempat, personil dan kemampuan teknis. Pada pelaksanakan proyek Online Trading System ini dilakukan pemilihan personel, negosiasi, merekrut, serta pembinaan tim kerja yang efektif yang memiliki kemampuan teknis dan menguasai teknologi proyek yang akan dikerjakan. Kelima, pemantauan, pengendalian, dan feedback. Pada proses ini dilakukan pemantauan, pengendalian, dan feedback selama proyek berjalan guna mengetahui sejauh mana hasil pelaksanaan dibandingkan dengan perencanaan terutama anggaran. Dengan demikian dapat diadakan koreksi sesuai keperluan.

Dalam Proyek Online Trading System, aktivitasnya dibagi menjadi beberapa kegiatan utama dan sebagian kegiatan utama tersebut memiliki kegiatan pendukung. Kegiatan yang dilaksanakan adalah pertama, planning, pada tahap ini perusahaan 
melakukan perencanaan dan pengumpulan data yang diperlukan untuk proyek Online Trading System. Kedua, initiation, pada tahap ini pihak perusahaan menyediakan seluruh hardware yang dibutuhkan dan menyiapkan hardware tersebut untuk dapat mendukung pembuatan proyek Online Trading System, seperti menyediakan server, networking device, module package, dan software.

Ketiga, design. Pada tahap ini dilakukan perancangan dan desain terhadap fitur yang diinginkan oleh perusahaan. Desain terdiri dari Global Desain; Desain Client, seperti main form, market information screen, portofolio, order screen, chart screen, news screen, ticker, report; Desain Server, seperti load balancing, client management, price dissemination, tick server, news server, chart server, report server. Keempat, Coding. Pada tahap ini dilakukan pembuatan coding pada desain yang sudah ada. Tahap itu terdiri dari Coding Client, seperti main form, market information screen, portofolio, order screen, chart screen, news screen, ticker, report; Coding Server, seperti load balancing, client management, price dissemination, tick server, news server, chart server, report server.

Kelima, Testing. Pada tahap ini dilakukan pengujian terhadap fitur yang telah dibuat apakah telah berjalan sebagai mestinya dan sesuai dengan yang direncanakan sebelumnya, seperti internal testing dan external testing. Keenam, Implementation. Pada tahap ini dilakukan peng-install-an hasil pembuatan proyek. Selain itu juga dilakukan pelatihan kepada bagian Client dan bagian Server.

Dari pembahasan Online Trading System tersebut, dapat diperkirakan ada beberapa risiko yang mungkin terjadi dalam pembuatan dan pelaksanaan proyek ini, diantaranya, pertama, mundurnya waktu pengerjaan proyek. Waktu yang dibutuhkan dalam pengerjaan proyek Online Trading System ini dapat semakin panjang apabila waktu pengerjaan coding sering terjadi error dan tim proyek yang mengerjakan coding kurang memahami proses bisnis. Kedua, membengkaknya biaya proyek. Membengkaknya biaya proyek Online Trading System dapat disebabkan oleh adanya anggota tim pengerjaan proyek yang mengundurkan diri atau adanya penambahan requirement selama pengembangan proyek sedang berlangsung. Ketiga, keterlambatan penerimaan hardware. Keterlambatan penerimaan hardware dapat disebabkan oleh ketidaktepatan waktu pengiriman dari supplier atau hardware yang dipesan tidak semua dimiliki oleh supplier sehingga supplier harus melakukan pemesanan ke distributor terlebih dahulu yang menyebabkan keterlambatan pengiriman hardware dari waktu yang telah disepakati. Keempat, terjadinya keterlambatan pemasangan communication line dari pihak vendor.

Dari identifikasi risiko yang telah diuraikan tersebut, solusi yang dapat disarankan adalah selalu melakukan pengetesan terhadap setiap modul coding yang telah diselesaikan; Project Leader memberikan pengarahan mengenai proses bisnis yang ada; Membuat perjanjian kontrak kerja dengan tim kerja proyek; Memaparkan semua kendala yang ada selama pengerjaan proyek dan mencari solusi bersama-sama saat progress 
meeting; Melakukan perjanjian dengan bagian pihak supplier mengenai tanggal pengiriman hardware dan beberapa hari sebelum tanggal pengiriman melakukan konfirmasi ulang tanggal pengirimannya; Mencari alternatif dari supplier lain yang memiliki hardware yang diperlukan; Meminta konfirmasi kepada vendor mengenai jadwal pemasangan communication line.

Struktur organisasi proyek yang diusulkan dalam manajemen proyek ini dengan mempertimbangkan keterlibatan pihak internal perusahaan maupun posisi konsultan dari eksternal perusahaan adalah sebagai berikut.

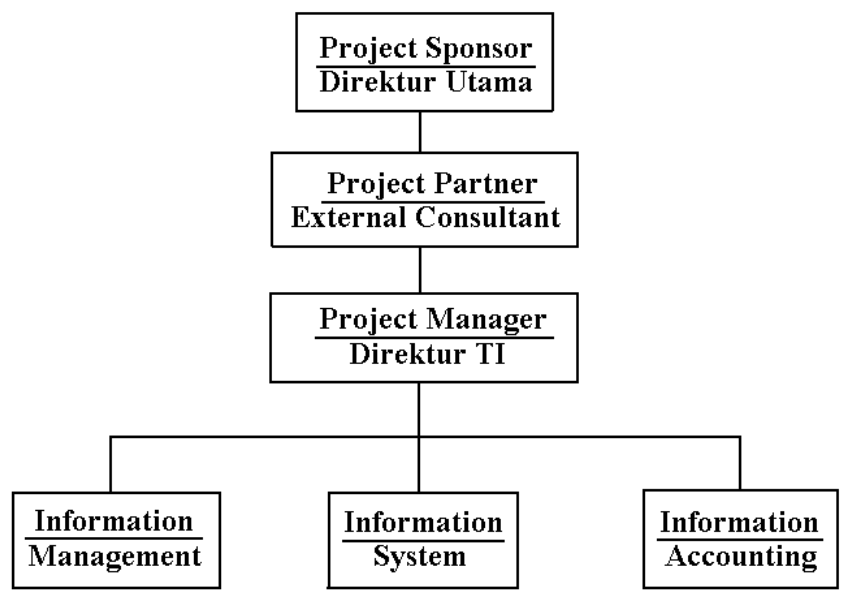

Gambar 1 Struktur Organisasi Proyek yang Diusulkan dalam Manajemen Proyek

Rancangan Work Breakdown structure sebagai berikut.

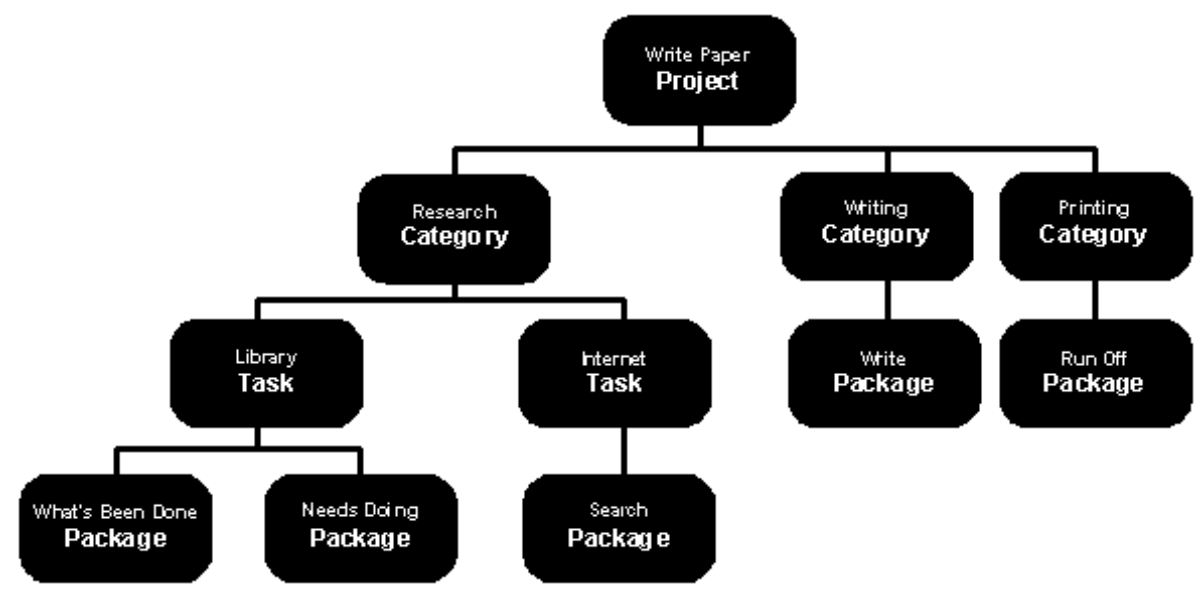

Gambar 2 Rancangan Work Breakdown structure 
Diagram jaringan kerja untuk memantau tahapan dalam proyek beserta prediksi waktu dan ketergantungan satu aktivitas dengan aktivitas lainnya dapat terlihat sebagai berikut.

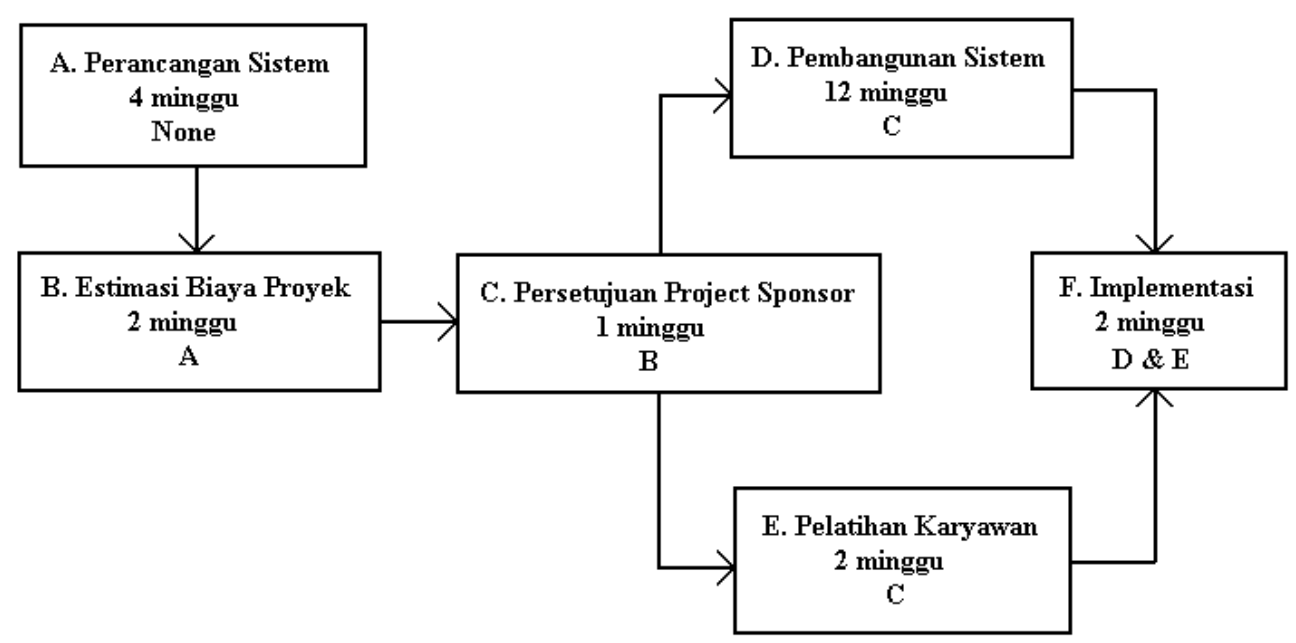

Gambar 3 Diagram Jaringan Kerja untuk Memantau Tahapan dalam Proyek Beserta Prediksi Waktu dan Ketergantungan Satu Aktivitas dengan Aktivitas Lainnya

Gantt Chart dipergunakan dalam Penjadwalan proyek sebagai berikut.

Tabel 1 Gantt Chart Dipergunakan dalam Penjadwalan Proyek

\begin{tabular}{|c|c|c|c|c|c|c|c|c|c|c|c|c|}
\hline \multirow{2}{*}{\multicolumn{2}{|c|}{ Activity }} & \multicolumn{11}{|c|}{ Minggu } \\
\hline & & & 23 & & 6 & 7 & & & $2[13]_{14}$ & $\left.1518\right|_{13}$ & & $20 \mid 21$ \\
\hline $\bar{A}$ & Perancangan Sistem & $\mathrm{x}$ & $x$ & $\mathrm{x}$ & & & & & & & & \\
\hline B & Estimasi Biaya Proyek & & & & $\mathrm{x}$ & & & & & & & \\
\hline $\mathrm{C}$ & Persetujuan Project Sponsor & & & & & $\mathrm{x}$ & & & & & & \\
\hline $\mathrm{D}$ & Pembangunan Sistem & & & & & & $\mathrm{x}$ & & $\mathrm{x} \times \mathrm{x}$ & $\mathrm{x} \times \mathrm{x} \times$ & $\mathrm{x} \mid \mathrm{x}$ & \\
\hline $\mathrm{E}$ & Pelatihan Karyawan & & & & & & $\mathrm{x}$ & & & & & \\
\hline $\mathrm{F}$ & Implementasi & & & & & & & & & & & $\mathrm{x} x$ \\
\hline
\end{tabular}




\section{PENUTUP}

Berdasarkan pengerjaan proyek Online Trading System yang telah dilakukan, dapat disimpulkan beberapa hal, pertama dalam pelaksanaan proyek Online Trading System ini terdapat enam tahapan yang terdiri dari Planning, Initiation, Design, Coding, Testing, Implementation. Kedua, komposisi dari tim proyek Online Trading System terdiri dari 1 orang Project Leader, 2 orang Server Side, 5 orang Client Side, 4 orang Database/ Network, 2 orang Analysis/Design. Ketiga, pengendalian terhadap proyek Online Trading System berjalan dengan baik.

\section{DAFTAR PUSTAKA}

Anthony, Robert N. and Vijay Govindarajan. 2007. Management Control Systems International Edition. $12^{\text {th }}$ Edition. New York: McGraw - Hill.

Gray, Clifford F. and Erik W. Lanson. 2000. Project Management: The Managerial Process International Edition. New York: McGraw - Hill.

Nicholas, John. M. 2001. Project Management for Business and Technology. New Jersey: Prentice Hall.

Olson, David L. 2003. Introduction to Information System Project Management. New York: McGraw-Hill.

Pressman, Roger S. 2003. Software Engineering: A Practitioners Approach. New York: McGraw-Hill.

Robbins, Stephen P. and Mary Coulter. 2005. Management. Edisi ke-8. New Jersey: Pearson Prentice Hall.

Santoso, Budi. 2003. Manajemen Proyek. Jakarta: Guna Widya.

Schwalbe, Kathy. 2006. Information Technology Project Managemen. $4^{\text {th }}$ Edition. Boston, Massachusetts: Couerse Technology.

Soeharto, Iman. 2001. Manajemen Proyek dari Konseptual Sampai Operasional, Jilid 2, Edisi ke-2. Jakarta: Erlangga. 